\title{
The use of opioid analgesics in chronic pain therapy - a retrospective, single-center study
}

\begin{abstract}
Introduction: The use of opioids is fundamental in moderate and severe pain management. There is an increase in opioids use in highly developed countries, while at the same time in other countries, difficulties in access to appropriate pain treatment are observed. The aim of the study was to determine the use of opioids in the treatment of chronic cancer-related and non-cancer pain.

Material and methods: The study covered the medical documentation of patients under the care of the Pain Medicine Clinic, Palliative Medicine Clinic and Hospice in the period 01.01.2017-30.04.2017 which reported: sex, age, duration of medical services, primary diagnosis, opioid treatment - pharmacological substances, a form of supply and side effects.

Results. In the study, 634 medical consultations of 196 patients were analyzed and 32 (16\%) of them were cancer patients. The predominant cause of pain were degenerative diseases, disorders of the spinal nerves and nerve plexuses. Oxycodone was most often used as a monotherapy for cancer and non-cancer pain. Transdermal buprenorphine was significantly more frequently used in non-cancer pain and transdermal fentanyl was more frequently administered in cancer-related pain. In the group of cancer patients, the principles of multi-modal therapy were more often applied and no adverse effects were noted.

Conclusions. Opioids are the primary method in pharmacotherapy at the specialist level. Oxycodone is widely used in monotherapy of cancer-related and non-cancer pain. Various forms of the supply of opioids in the therapy of chronic cancer pain is not associated with the risk of side effects.
\end{abstract}

Palliat Med Pract 2019; 13, 1: 11-16

\section{Introduction}

Pain is an unpleasant subjective experience with a multi-directional aspect: psychological, social and health, and at the same time constitutes a significant, current and interdisciplinary medical issue [1, 2]. Pharmacological management is one of the methods of pain treatment. Opioid analgesics play a fundamental role in the pharmacotherapy of moderate to severe pain, both cancer and non-cancer pain. In moderate pain intensity defined in the Numerical Rating Scale (NRS) 4-6, step 2 opioids: tramadol, dihydrocodeine, codeine or small doses of step 3 opioids are recommended. Pain, corresponding to NRS $7-10$, is an indication for the use of step 3 opioids at higher doses morphine, oxycodone, alternatively fentanyl or buprenorphine in the transdermal patch. Numerous publications indicate the increasing use of opioids in

Address for correspondence:

Urszula Kościuczuk

Pain Medicine Clinic, Bialystok

e-mail: urszula.kosciuczuk@umb.edu.pl 
recent decades in highly developed countries, while at the same time pointing to the difficulties in access to appropriate treatment and pain relief $[3,4]$.

In Poland, specialist and multidisciplinary treatment including pharmacology, interventional techniques, rehabilitation, and psychological interventions of patients with chronic pain take place in Pain Medicine Clinics, Palliative Medicine Clinics, Home and Stationary Hospices and In-patient Palliative Medicine Units in hospitals. The use of opioids in the treatment of chronic cancer and non-cancer pain still raises social controversies due to fears of the occurrence of mental and physical dependence. Given the dynamically growing number of people suffering from chronic pain and the increasing use of opioids in the treatment, medical personnel must demonstrate specialized knowledge and attention to this group of patients [5].

The use of opioids in pain treatment may be associated with a number of side effects and disorders. Many of them are widely known and evaluated in a routine visit. Some of them are described as cognitive decline and memory loss. The question arises whether the use of opioids for analgesia influences cognitive processes assessed in a typical medical examination on a standard control visit: Is this effect commonly reported by patients? The aim of this study is to determine the differentiation of using opioids in the treatment of cancer-related and non-cancer chronic pain. The second problem is what side effects of opioids are shown in the medical records on routine patient visits. This work is part of the project: Evaluation of pharmacological chronic pain treatment.

\section{Material and methods}

The study consisted of the analysis of medical documentation of patients under the care of the Pain Medicine Clinic, Palliative Medicine Clinic, Home Hospice in Białystok, Poland in the period from 01.01.2017 to 30.04.2017. The data including information on sex, age, duration of treatment, principal diagnosis, opioids prescriptions, applied pharmacological treatment with opioids - pharmacological substances, form of supply, side effects (constipation, skin changes, nausea, vomiting, cognitive disorders, memory loss, the need for psychological or psychiatric consultation) were noticed.

In all patients, in the field of nursing activities before a medical examination, the physical condition was assessed by measuring blood pressure by the non-invasive method, heart rate, and pulsoximetry. NRS and visual-analogue scale (VAS) were used to analyze the intensity of pain. Another nursing element was a closed question questionnaire aimed at identifying behaviours related to the abuse of opioid drugs and accepting treatment. As the study was observational in its nature an Ethical Committee approval was not required. The total group of patients, the total number of medical consultations and the total number of opioids prescriptions were noticed.

Conformity assessment of the empirical distribution of studied parameters was performed using the Shapiro-Wilk test. Since most empirical obtained distributions differed significantly from normal distributions, a comparison of the data was assessed by non-parametric tests. The differences in the level of parameters being considered between the groups of patients were analyzed using the Mann-Whitney $\mathrm{U}$ test. Coefficient correlation was calculated using Spearman's rank method. Probability values of $\mathrm{p}<0.05$ were accepted as significant. Group data were expressed as medians and ranged when appropriate. Obtained results were subjected to statistical analysis using the STATISTICA 12.0 (StatSoft Inc., Tulsa, OK, United States) software.

\section{Results}

The characteristics of the patients studied are presented in Table 1. In the group of patients with chronic non-cancer pain, the most frequent cause for providing medical care were classified by International Classification Diseases (ICD-10) as chronic pain ( $R$ 52.1), pain in the course of spine degenerative disease ( $M$ 51, M 15, M 50, M 47), hip joints ( $M$ 16) and disorders of spinal nerves and nerve plexuses

Table 1. Characteristic of study group. Diagnosis in chronic non-cancer pain according to ICD-10 classification: R52.1, G54, M15, M16, M17, M47, M50, M51

\begin{tabular}{|l|c|}
\hline $\begin{array}{l}\text { Total number of patients/ } \\
\text { /number of medical consultations }\end{array}$ & $196 / 634$ \\
\hline Age in years, mean (range) & $66.3(33-101)$ \\
\hline Female & 114 \\
\hline Male & 82 \\
\hline Pain Medicine Clinic & 164 \\
\hline Palliative Medicine Clinic & 24 \\
\hline Home Hospice & 8 \\
\hline Cancer diagnosis & 32 \\
\hline Non-cancer diagnosis & 164 \\
\hline R 52.1 & 52 \\
\hline G 54 & 36 \\
\hline M 15, M 16, M 17, M 47, M 50, M 51 & 76 \\
\hline
\end{tabular}




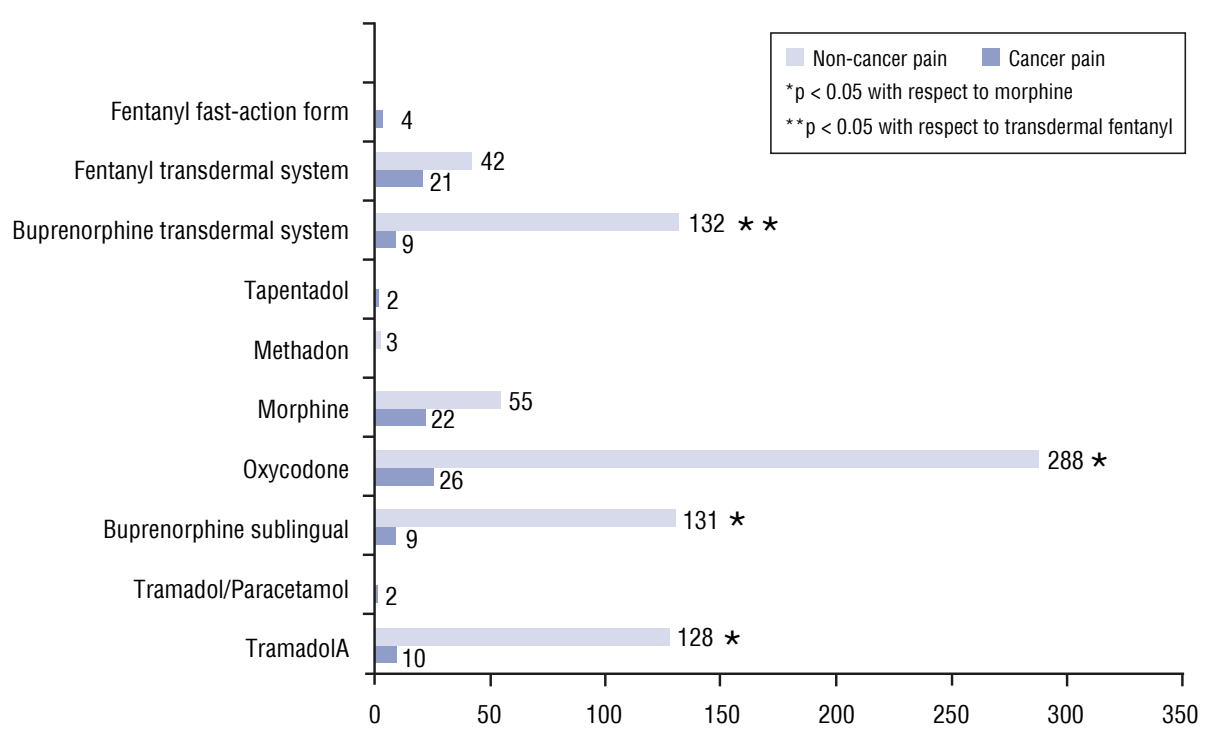

Figure 1. The use of opioids in the treatment of cancer and non-cancer pain. Numbers present total specific opioids drug prescriptions

(G 54). The group of $32(16.3 \%)$ patients were treated for cancer pain.

The analysis presented that in non-cancer pain, only please provide a number of patients $5 \%$ of the patients were treated with opioid therapy before a visit to the Pain Medicine Clinic, most often with transdermal buprenorphine. Among the patients who were initially provided with services at the Pain Medicine Clinic, opioids were prescribed in a number of patients please $20 \%$ of cases.

The analysis showed that in the total study group (196 patients) 634 medical consultations were performed and opioids were prescribed 884 times. The oral route of opioids administration in non-cancer pain treatment was used 605 times and transdermal patches were administered 174 times. In the treatment of non-cancer pain with the use of opioids, therapy with oral oxycodone (288 times) was significantly more frequent $(p<0.05)$ than with transdermal buprenorphine (132 times). The analysis showed that oral tramadol, oral oxycodone and buprenorphine in the sublingual form were used significantly more frequently than morphine products, while oxycodone was recommended considerably more often for all oral analgesics. It was noticed that transdermal buprenorphine was used much more frequently than transdermal fentanyl ( $p<0.05$ ). The characteristic of types of opioids and correlations are presented in Figure 1.

In the analyzed period, 16 adverse reactions related to non-cancer pain treatment were reported, including nausea and vomiting accounted please provide number of patients with all percentage values $40 \%$, skin lesions and itching $40 \%$, constipation for
$15 \%$, persistent, mental changes $5 \%$ - in these cases patients referred for specialist treatment - psychological and psychiatric. The analysis showed that there is no statistical correlation between the occurrence of adverse reactions associated with the use of oral opioids and age and sex of patients. However, there was a correlation between the presence of adverse reactions and transdermal opioids. The results of the study demonstrated a correlation of side effects and the use of buprenorphine ( $p=0.05$ ), no correlation observed with fentanyl products. In non-cancer pain therapy, the side effects were reported in 13 cases of transdermal opioids, which is $7.47 \%$ of the total group. Side effects have also been reported for three opioid applications in the oral form, accounting for only $0.49 \%$ of all applications.

In the study, 105 opioids prescriptions were provided for a total of 32 cancer patients ( 15 women with an average age of 72.6 and 17 men with an average age of 68.2 years, the average duration of medical care was 29.4 months, average 1.25 visits/month/patient). In a number of patients please 33\% of cases, monotherapy used in the treatment, with the most common use of oxycodone products. The multi-modal pain therapy was noticed in a number of patients please $67 \%$ of cases, it is shown that the most common combinations were fentanyl or buprenorphine in the transdermal system and oral morphine. No side effects have been reported in those subjects. A summary of the results:

1. Oral forms of opioids were the most common used in non-cancer pain therapy.

2. Oxycodone was used more frequently in cancer and non-cancer pain therapy. 
3. Buprenorphine transdermal systems in non-cancer pain and fentanyl transdermal form in cancer-related pain were more frequently used.

4. The correlation of adverse reactions and the use of opioids in the treatment of non-cancer pain was noticed. There was no correlation in the group of cancer patients.

5. Combination of oral and transdermal forms of opioids in cancer pain therapy was most popular.

\section{Discussion}

During the 4-month follow-up carried out in Pain Clinic, the Palliative Medicine Clinic and Home Hospice care, it was shown that oxycodone and buprenorphine were significantly more frequently recommended than other opioids in the treatment of non-cancer pain. These drugs were most often used in the treatment of strong refractory pain in the course of degenerative disease of the spine, joints, and other musculoskeletal chronic pain. Also were observed that the treatment of non-cancer pain, a monotherapy regimen was much more common compare to cancer-related pain. It has been observed that patients referred to pain clinics have pain opioid therapy which is ordered before arrival at the clinic and started by primary care. The most often used opioid before visiting a specialist pain clinic was buprenorphine. The results of our study are comparable with the analyzes of opioid prescribing for chronic musculoskeletal pain in UK primary care [6]. Also earlier our analysis of the use of opioids in the clinic demonstrated that transdermal buprenorphine constituted about $50 \%$ of the prescription of opioids in non-cancer pain [5]. In our study, it was demonstrated that, unlike the treatment of non-cancer pain, the pain associated with cancer required multi-modal therapy. In the treatment of cancer-related pain, the most common form of short-acting morphine is used in combination with the fentanyl or buprenorphine transdermal system. The results of our study indicate that the use of synthetic opioids - in this case, oxycodone and various forms of buprenorphine - was significantly more frequent compared to the natural opiate, which is morphine. These results show that therapy based on synthetic opioids is more preferred in non-cancer pain.

The specific objective of the study was to analyze the use of opioids, and especially the answer to the question of whether the doctor prefers the choice of opioids? No differences were found in the use of opioids between individual doctors, especially there was no difference depending on the place where the medicine was being prescribed. The type of opioid selection depends on the cause of pain and when the pain was of non-cancer origin, mainly oxycodone and buprenorphine were used. Conversely, in patients with cancer-related pain, the therapy was complex and a wider choice of drugs was used.

Both in the world and in Poland, there is an increase in opiate consumption, especially in non-cancer pain [7]. According to previous data from the literature, the use of synthetic opioids is associated with lower risk of cognitive, gastrointestinal disorders, drug interactions compared to treatment associated with the use of morphine. However, in recent years, the phenomenon of excessive use of opioids, especially oxycodone, has been observed in the USA in particular, not related to the occurrence of pain. This is related to the occurrence of a number of side effects including overdose.

It should be noted that irrespective of the dose of the drug, CNS side effects may occur. It is really thought-provoking that the small group of patients had cognitive disorders occurring after using the opioids. According to the literature, such symptoms may occur and they are most frequently reported in the USA [8-15]. Mumba et al. presented that mental and cognitive dysfunction associated with opioid therapy appears in about $10 \%$ of patients [16]. In experimental studies, it has been described that the opioid dose is associated with the functional stimulation of the hippocampus and amygdala structures with concurrent inhibition of brain cerebral cortex, and large opioid doses also inhibit the neuronal activity of the thalamus. As a result of the described changes, there is a disturbance of motor, sensory and cognitive functions and emotional disturbances. The assessment of cognitive impairment is difficult and requires the use of specialist assessment, including tests and psychological assessment [1, 2].

During the period 2000-2015 in Poland there was a significant increase in the use of opioids. The progressive increase in the use of opioids in analgesic therapy had been reported since 2013, including step 3 opioids, accounted for $41 \%$ of consumption. Many years of observation indicated increased use of both step 2 and step 3 opioids, which reached a value from $14.1 \mathrm{mg}$ oral morphine/patient in 2000 to $44.4 \mathrm{mg}$ in 2015. Regarding step 2 opioids, the increase was less dynamic and reached values from $21.9 \mathrm{mg}$ oral morphine equivalent dose (2000) up to $59 \mathrm{mg}$ (2015). When analyzing the group of step 3 opioids during the study period, the authors showed the reduced use of morphine. In the initial stage of observation, morphine was an opioid widely used and accounted for about $75 \%$ of all opioids used in pain therapy. In 
2015, in comparison to 2000, it was used in size range from 8.9 to $10 \mathrm{mg} /$ patient and currently, this compound remains in the third place in the classification of the use of opioids. In the analyzed period, there was a systematic increase in the use of opioid medications in the form of transdermal patches - fentanyl and buprenorphine. The authors pointed out that oxycodone, which has been available in Poland since 2009, remains in increased use and currently, it occupies the 4th place in the group of step 3 opioids. Methadone and pethidine have less importance in the treatment of pain. In the group of step 2 opioids, tramadol, which at the same time constituted $50 \%$ of all opioids, was used most frequently in the studied period. The use of dihydrocodeine is constant and reaches $0.7-0.8 \mathrm{mg}$ of oral morphine/patient. In 2000 step 3 opioids constituted $34 \%$ of all prescribed opioids, however, in the period 2013-2015 there was an increase to $41 \%$ [17].

Many interdisciplinary publications emphasize that the use of opioids in the treatment of chronic pain has a strong medical recommendation [18-22]. In our study, a small aspect of chronic pain therapy limited only to the use of opioid drugs was analyzed. The study included a 4-month period of medical services in the Pain Medicine Clinic, Palliative Medicine Clinic and Home Hospice where anesthesiologists and palliative medicine specialists work. The results of our study are consistent with the observations presented in numerous publications, which indicate that oxycodone and buprenorphine are most often used in the treatment of non-cancer pain, while multi-modal therapy using morphine and another step 3 opioids is the fundamental principle treatment of cancer-related pain. The obtained results should be confirmed by multi-centre study in a more extended period.

\section{Conclusions}

1. Opioids are the primary method in pharmacotherapy at the specialist level in palliative medicine.

2. Oxycodone is the most popular and widely used in cancer and non-cancer pain.

3. The occurrence of side effects in the form of mental disorders during opioid therapy is low.

\section{References}

1. Manchikanti L, Kaye AM, Knezevic NN, et al. Responsible, Safe, and Effective Prescription of Opioids for Chronic Non-Cancer Pain: American Society of Interventional Pain Physicians (ASIPP) Guidelines. Pain Physician. 2017; 20(2S): S3-S92, indexed in Pubmed: 28226332.

2. Wordliczek J, Kotlińska-Lemieszek A, Leppert W, et al. Farmakoterapia bólu u chorych na nowotwory - zalecenia Polskiego Towarzystwa Badania Bólu, Polskiego Towarzy- stwa Medycyny Paliatywnej, Polskiego Towarzystwa Onkologicznego, Polskiego Towarzystwa Medycyny Rodzinnej, Polskiego Towarzystwa Anestezjologii i Intensywnej terapii. Ból. 2017; 18: 11-53.

3. Ciałkowska-Rysz A, Dzierżanowski T. Podstawowe zasady farmakoterapii bólu u chorych na nowotwory i inne przewlekłe, postępujące, zagrażające życiu choroby. Med Paliat. 2014; 6: 1-6.

4. Misiołek H, Mayzner-Zawadzka E, Dobrogowski J, et al. Zalecenia 2011- postępowanie w bólu ostrym i pooperacyjnym. Ból. 2011; 12: 1-26.

5. Jakubów P, Kosel J, Kościuczuk U, et al. Leczenie bólu nienowotworowego buprenorfiną. Med Paliat. 2016; 8: 80-87.

6. Ashaye T, Hounsome N, Carnes D, et al. COPERS Study Team (ISRCTN 24426731).. Opioid prescribing for chronic musculoskeletal pain in UK primary care: results from a cohort analysis of the COPERS trial. BMJ Open. 2018; 8(6): e019491, doi: 10.1136/bmjopen-2017-019491, indexed in Pubmed: 29880563.

7. Dzierżanowski T, Ciałkowska-Rysz A. Accessibility of opioid analgesics and barriers to optimal chronic pain treatment in Poland in 2000-2015. Support Care Cancer. 2017; 25(3): 775-781, doi: 10.1007/s00520-016-3460-3, indexed in Pubmed: 27771783.

8. Von Korff MR. Long-term use of opioids for complex chronic pain. Best Pract Res Clin Rheumatol. 2013; 27(5): 663-672, doi: 10.1016/j.berh.2013.09.011, indexed in Pubmed: 24315147.

9. Khoury M, Caspi S, Stalnikowics R, et al. Emergency Department Administration of Oxycodone by Nurses Treating Musculoskeletal Pain: An Observational Prospective. Isr Med Assoc J. 2018; 5(20): 281-285, indexed in Pubmed: 29761672.

10. Dobrogowski J, Przeklasa-Muszyńska A, Woroń J, et al. Zasady kojarzenia leków w terapii bólu. Med Paliat Prakt. 2007; 1: 6-15.

11. Woroń J, Engel Z. Skojarzona farmakoterapia bólu, czyli o zasadach racjonalnej politerapii bólu. Anestezjol Ratow. 2012; 6: 89-93.

12. Dobrogowski J. Wordliczek J. Przeklasa-Muszyńska A. Zastosowanie silnie działających opioidów w leczeniu bólu nienowotworowego. Med Paliat Prakt. 2007; 1: 43-48.

13. Leppert W. Postępy w leczeniu farmakologicznym bólu nowotworowego analgetykami opioidowymi. Współcz Onkol. 2009; 13: 66-73.

14. Modlińska A. Zaparcia indukowane opioidami w bólu przewlekłym- praktyczne aspekty zastosowania oksykodonu z naloksonem. Med Paliat Prakt. 2013; 7: 1-5.

15. Jakubów P, Kościuczuk U, Kosel J. Ocena zastosowania tapentadolu w uporczywym bólu pochodzenia neuropatycznego w bólu nowotworowym. Med Paliat. 2017; 9: 225-230.

16. Mumba MN, Findlay L, Snow DE. Treatment Options for Opioid Use Disorders: A Review of the Relevant Literature. J Addict Nurs. 2018; 29(3): 221-225, doi: 10.1097/JAN.0000000000000241, indexed in Pubmed: 30180011.

17. Dzierżanowski T. Ciałkowska-Rysz A. Tapentadol w leczeniu przewlekłego bólu związanego z nowotworem. Med Paliat. 2016; 8: 157-163.

18. Hartrick CT, Rozek RJ. Tapentadol in pain management: a $\mu$-opioid receptor agonist and noradrenaline reuptake inhibitor. CNS Drugs. 2011; 25(5): 359-370, doi: 10.2165/11589080-000000000-00000, indexed in Pubmed: 21476608.

19. Mercadante $\mathrm{S}$. The role of tapentadol as a strong opioid in cancer pain management: a systematic and critical review. Curr Med Res Opin. 2017; 33(11): 1965-1969, doi: 
10.1080/03007995.2017.1379981, indexed in Pubmed: 28906155.

20. Garland EL, Froeliger B, Zeidan F, et al. The downward spiral of chronic pain, prescription opioid misuse, and addiction: cognitive, affective, and neuropsychopharmacologic pathways. Neurosci Biobehav Rev. 2013; 37(10 Pt 2): 2597-2607, doi: 10.1016/j.neubiorev.2013.08.006, indexed in Pubmed: 23988582.
21. Leppert W, Forycka M, Nosek K. Ból przebijający i epizodyczny u chorych na nowotwory. Med Paliat. 2016; 8: 9-16.

22. Trescot AM, Helm S, Hansen $\mathrm{H}$, et al. Opioids in the management of chronic non-cancer pain: an update of American Society of the Interventional Pain Physicians' (ASIPP) Guidelines. Pain Physician. 2008; 11(2 Suppl): S5-S62, indexed in Pubmed: 18443640. 